\title{
GEOTHERMAL DEVELOPMENT PLAN: YUMA COUNTY
}

\author{
Prepared by
}

The Arizona Geothermal Commercialization Team

Don H. White, Ph.D., Principal Investigator

Larry A. Goldstone, Project Manager

Arizona Geological Survey
Open-File Report 80-8

1980

\section{Arizona Geological Survey}

416 W. Congress, Suite \#100, Tucson, Arizona 85701

State Contractor:

Arizona Solar Energy Commission James F. Warnock, Jr., Director

Frank Mancini, Ph.D., Associate Director

1700 West Washington Phoenix, Arizona 85007

Work performed under Contract No. DE-FC03-80RA50076

Modification No. A-001

Evaluation of Geothermal Energy in Arizona

U.S. Department of Energy San Francisco Office

Subcontract 114-80 with Department of Chemical Engineering

University of Arizona Tucson, Arizona 85721

Prepared under U.S. Department of Energy Contract EG-77-S-02-4362

This report is preliminary and has not been edited

or reviewed for conformity with Arizona Geological Survey siandards 



\section{ACKNOWLEDGEMENTS}

The Arizona Geothermal Commercialization Team has been comprised of many individuals over the past several years. Recognition is extended to the following professors who have contributed to the Team's efforts: John Kessler, Ph.D.; Mike Pasqualetti, Ph.D.; and David Wolf, Ph.D.

Group leaders were Mohamad Chehab, Larry Goldstone, Lani Malysa and Bill Weibel.

Other contributors include Cherif Ballamane, Ronda Bitterli, Wei-hsin (Alex) Chung, Elizabeth Foster, Jeff Hagen, Akram Hasan, Greta Jensen, Gary Kyle, Timeral Rowe, Edward Seames and John Westover.

The following people were special task contributors: Don Astrom, Greta Jensen, Iftikhar Khan, Doug Linkhart, Lanl Malysa, Mobin Qaheri, Xavier Suarez, Charles Tabet and Steve Unguran.

In addition, W. Richard Hahman, Sr., Claudia Stone and Jim Witcher of the Arizona Bureau of Geology and Mineral Technology-Geothermal Group deserve recognition for their contributions and assistance.

Special thanks are extended to Bette Holt for drafting some of the figures and to Peggy Jackson and Lee DeYonghe for their assistance in typing the final manuscript. 
TABLE OF CONTENTS

Page

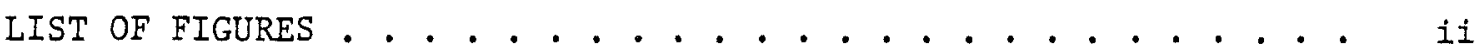

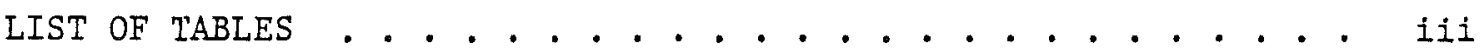

INTRODUCTION • . . . . . . . . . . . . . . . . . . . . . . . 1

AREA DEVELOPMENT PLANS . . . . . . . . . . . . . . . . . . . . 2

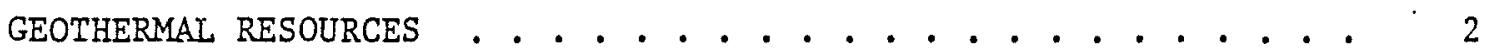

ECONOMY . . . . . . . . . . . . . . . . . . . . . . . .

Population . . . . . . . . . . . . . . . . . . . . . . . . 6

Growth . . . . . . . . . . . . . . . . . . . . . . . . . . . . . . . 7

Industry and Employment . . . . . . . . . . . . . . . . . 7

LAND OWNERSHIP . . . . . . . . . . . . . . . . . . . . . . . . 9

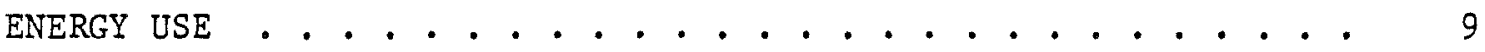

WATER . . . . . . . . . . . . . . . . . . . . . . . . . 11

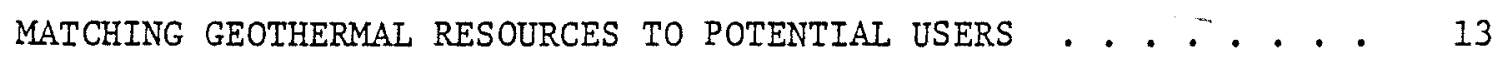

APPENDIX A . . . . . . . . . . . . . . . . . . . . . . . . . . . 18

BIBLIOGRAPHY • . . . . . . . . • . . . . . . . . . . 20 
1 Area Development Plans for Arizona

2 Arizona's Proven, Potential and Inferred Resources 4

3 Population Projections for Yuma County to $2020 \quad 8$

4 General Land Ownership Map for Yuma County 10

5 Projected Alternatives for Water Use in Yuma County 12

6 Projected Geothermal Heat On Line Under City Development 14

7 Projected Geothermal Heat On Line Under Private Development 15 
Table

Page

1 Some Common Conversion Factors

2 Proven and Potential Reservoirs of Yuma County of Less Than $1.2 \mathrm{Km}$ Depth

3 Breakdown of Land Ownership in Yuma County

4 Estimated Process Heat Energy Requirements.

5 Barrels of 011 Replaced by Geothermal Energy Per Year Process Heat Market 


\section{INTRODUCTION}

Alternative sources of energy will have to be developed as the availability of traditional energy resources continues to diminish. Arizona is supplied with geothermal reserves which could potentially supplement the existing energy supplies. Consequently, planning efforts have concentrated on, estimating the potential of geothermal energy utilization in Arizona and in providing information necessary for its prospective commercialization.

Geothermal commercialization plans were prepared for seven distinct intrastate subdivisions. The geothermal resource prospect and the potential geothermal uses for each area are discussed in separate Area Development Plans (ADPs). The major objective of the ADP is to provide information for the prospective development and commercialization of geothermal energy in the specified area. Attempts are made to match the available geothermal resources to potential residential, commercial, industrial and agricultural users.

This $\mathrm{ADP}$ is concerned with geothermal potential in Yuma County. One hot spring and 33 wells drilled in the county discharge water at temperatures sufficient for direct-use geothermal applications such as process heat and space heating and cooling. Currently, one industry within the county has been identified which may be able to use geothermal energy for its process heat requirements. Also, a computer simulation model was used to predict geothermal energy on line as a function of time under both private and city-owned utility development of the resource. 
AREA DEVEIOPMENT PLANS

Arizona bas been divided into seyen distinct single or multicounty subdivisions for which Area Development Plans (ADPs) for geothermal commercialization have been developed. A map of Arizona presented in Figure 1 shows these areas which are numbered in order of planning priority.

This ADP is concerned with Yuma County. Both metric and English units are provided in the text. Howeyer, only metric units appear in the tables and figures. For conventence, some common conversion factors are Iisted in Table 1.

TABLE 1: SOME COMMON CONVERSION FACTORS

Length and Volume Conversions:

To Conyert:

meters

kilometers

cubic kilometers

Iiters
- Multiply By:

3.281

0.6214

0.2399

0.2642
To Obtain:

feet

miles

cubic miles

gallons

Temperature Conversions: ${ }^{\circ} F=\left(1.8 \times{ }^{\circ} \mathrm{C}\right)+32$

GEOTHERMAL RESOURCES

Yuma County lies entirely within the Basin and Range physiographic province which is characterized by numerous mountain ranges rising abruptly from broad yalleys. At least five areas known to store thermal water at relatively shallow depths of less than $1200 \mathrm{~m}$ (3940 ft) are located within the county. Numbered boxes in Figure 2 identify these areas, Table 2 gives the location of each of these areas along with rough depth, volume and temperature estimates. 
PFlortities

I) Mar1copa

II) PIma

III) Grainam/Greerlee

IV) PInal

V) Tuma

VI) CochIse/Santa Cruz

VII) Northern Counties $(1,3,4,8,9,13)$

\section{County Names}

1. Apache

2. Cochise

3. Coconino

4. G11a

5. Graham

6. Greenlee

7. Maricopa

8. Mohave

9.- Navajo

10. Pima

11. Pinal

12. Santa Cruz

13. Yavapa1

14. Tuma

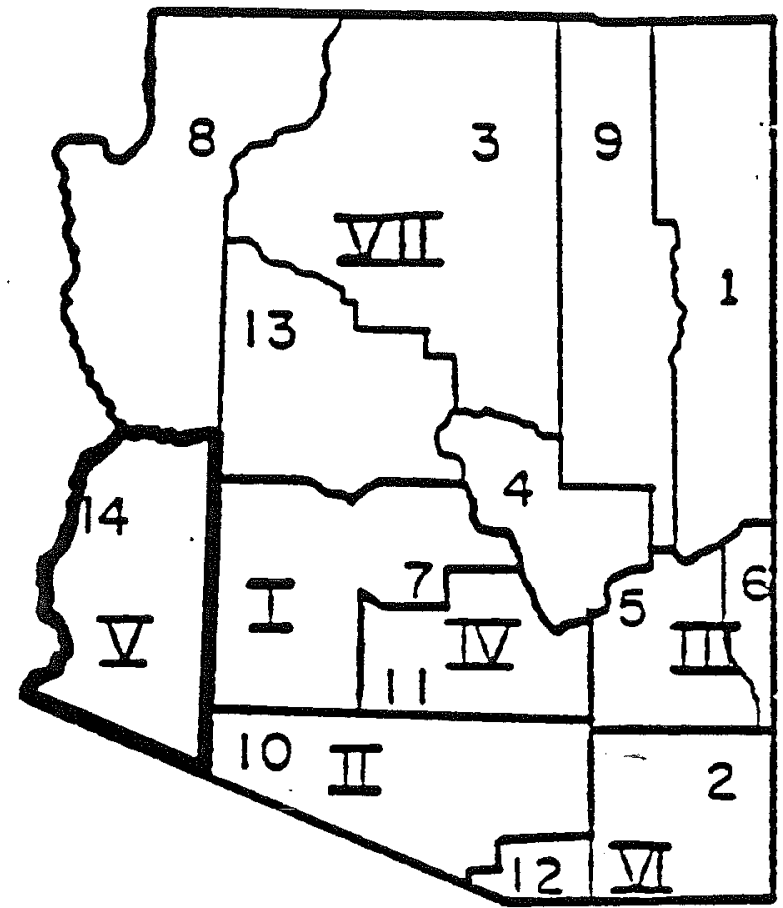

Figure 1: Area Development Plans for Arizona. 


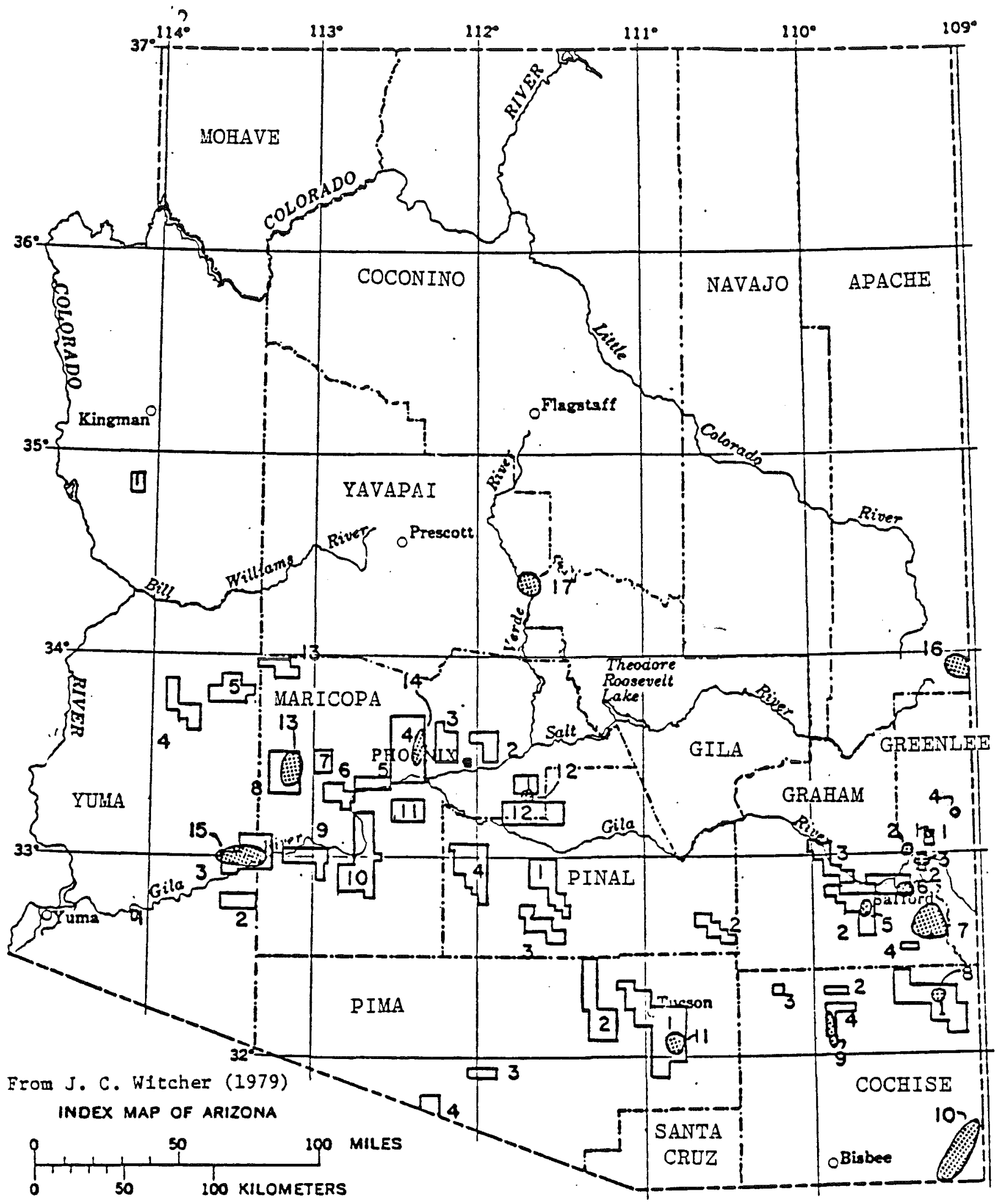

Figure 2: Arizona's Proven, Potential and Inferred Resources. 
TABLE 2: PROVEN AND POTENTIAL RESERVOIRS OF YUMA COUNTY OF LESS THAN 1.2 KM DEPTH Modified from Witcher (1979) Tr - Average reservolr temperature

\begin{tabular}{|c|c|c|c|c|c|c|c|c|}
\hline Area & Location & $\begin{array}{l}\text { Volume } \\
\left.(\mathrm{km})^{3}\right)\end{array}$ & & $\begin{array}{l}\text { Measured }\left({ }^{\circ} \mathrm{C}\right) \\
\text { Temperature }\end{array}$ & $\begin{array}{l}\text { Depth } \\
\text { (km) }\end{array}$ & $\operatorname{Tr}\left({ }^{\circ} \mathrm{C}\right)$ & $\begin{array}{l}\text { Geothermometry } \\
\text { Temperature }\left({ }^{\circ} \mathrm{C}\right)\end{array}$ & Method \\
\hline 1 & T8-9S, R19W & 3.1 & & $50-60$ & $<0.015$ & 60 & $60-70$ & Quartz \\
\hline 2 & $\mathrm{~T} 7-8 \mathrm{~S}, \mathrm{R} 11-12 \mathrm{~W}$ & 65.0 & & $30-40$ & $<0.21$ & 65 & $40-70$ & Chalcedony \\
\hline 3 & $\mathrm{~T} 4-6 \mathrm{~S}, \mathrm{R} 10-12 \mathrm{~W}$ & 148.6 & & $30-45$ & $<0.46$ & 70 & $60-80$ & Chalcedony \\
\hline 4 & T3-6N, R14-16W & 83.6 & $\cdot$ & $30-45$ & $<0.46$ & 60 & $40-70$ & Chalcedony \\
\hline 5 & $\mathrm{~T} 5-6 \mathrm{~N}, \mathrm{R} 11-13 \mathrm{~W}$ & 123.8 & & $30-40$ & $<0.46$ & 50 & $30-40$ & Chalcedony \\
\hline
\end{tabular}


One hot spring in Yuma County provides directly observable evidence of geothermal energy. Water discharged from the spring when it was flowing had a temperature of $60^{\circ} \mathrm{C}\left(140^{\circ} \mathrm{F}\right)$ and a total dissolved solids content of 2240 ppm.

Thirty-three thermal wells in the county discharge water at temperatures ranging from $35.0^{\circ} \mathrm{C}\left(95^{\circ} \mathrm{F}\right)$ to $42.5^{\circ} \mathrm{C}\left(108.5^{\circ} \mathrm{F}\right)$ and depths from $91 \mathrm{~m}(300 \mathrm{ft})$ to $602 \mathrm{~m}(1975 \mathrm{ft})$. Flow rates range from 2,271 to 12,665 liters per minute. Total dissolved solid content ranges from as low as 327 ppm to as high as $4450 \mathrm{ppm}$.

The Yuma area itself, located in the extreme southwestern corner of Arizona, lies principally in the Sonoran Desert subprovince of the Basin and Range physiographic province. A small portion of this area lies within the Salton Trough subprovince, a deep, sediment-filled structural basin extending through Mexico, Arizona and California. At least a dozen geothermal anomalies have been identified in the Salton Trough. These anomalies do not necessarily indicate a geothermal resource but they do indicate geothermal potential (Stone, 1981).

A forthcoming state geothermal map compiled by the Arizona Bureau of Geology and Mineral Technology and published by the National Oceanographic and Atmospheric Administration will provide a complete and updated listing of data concerning thermal well and spring locations as well as temperature and depth estimates, flow rates and total dissolved solids. This map will be avialable in late 1981. ECONOMY

\section{Population}

The 1980 population for Yuma County was 90,554. Total land area of 
the county is 9,991 square miles which results in a population density of 9 persons per square mile. However, over 50 percent of the population resides in the city of Yuma. Ethnic breakdown of the population is 65 percent white, 27 percent Hispanic, 4 percent Indian and 3 percent black. Growth

Between 1950 and 1960, the population of Yuma County increased at an average annual rate of 5.1 percent. From 1960 to 1970 , the population increased at a rate of 2.7 percent per year. These increases were slightly below the state annual average rates of 5.7 and 3.1 percent for 1950 to 1960 and 1960 to 1970, respectively. Figure 3 presents population projections to the year 2020. The implied annual growth rate over the next 40 years is almost two percent.

Industry and Employment

Agriculture, the primary employment sector in Yuma County, accounted for 33 percent of the county's employment in 1978 and 12 percent of its personal income in 1977. Yuma County produced 47.5 percent and 45.0 percent of the state's major citrus crops during the 1976-1977 and 1977-1978 seasons, respectively. Principal crops are cotton, hay, wheat, corn, barley and sugarbeets.

Recently, there has been a decline in total cash receipts from agricultural products in Yuma County. From 1976 to 1977, there was a decline of approximately 11.4 million dollars or 5.1 percent of total revenue from agriculture. This decrease is attributed to the decline in livestock receipts. Crop and citrus fruit receipts, however, will continue to prosper.

Presently, Yuma County has several light industries. These include men's clothing, paper plates, photo processing equipment and ceramic 


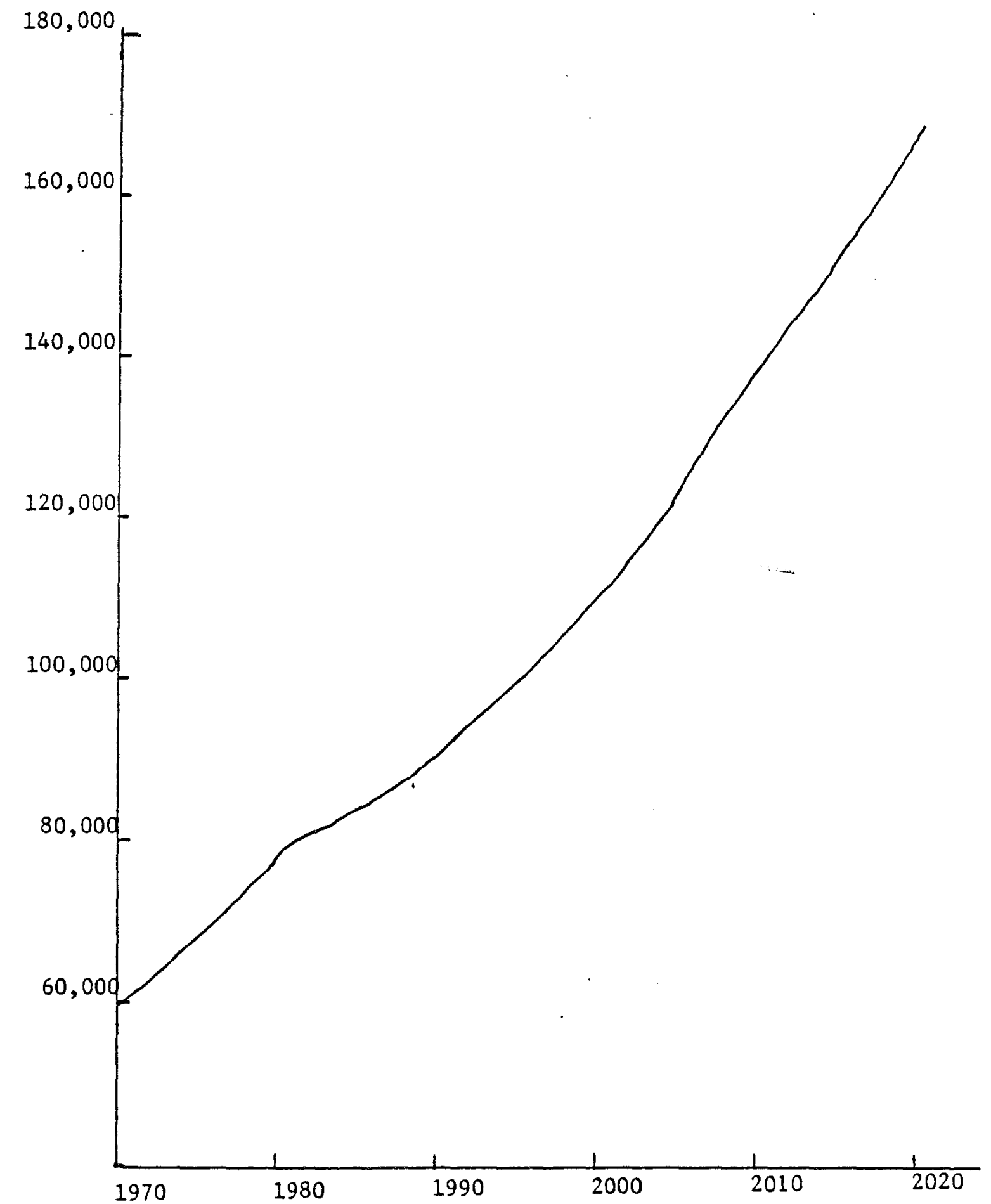

Figure 3: Population Projections for Yuma County to 2020. Source: Technical Advisory Committee 
highway markers. Yuma County also serves as a distributional center for McDonne11-Douglas Corp, Hughes Helicopter, Broder Machinery, and Lipe Clutel Division of Lipe-Rollway..

Yuma County's Chamber of Commerce is actively seeking and encouraging new industry. Several new industries are projected for the county. EAND : OWNERSHIP

Figure 4 presents a general land ownership map for Yuma County. The majority of the land is owned by the federal government. Table 3 shows acres owned by various sectors.

TABLE 3: BREAKDOWN OF LAND OWNERSHIP IN YUMA COUNTY

\begin{tabular}{lcc}
\hline Sector & Percentage & Total Acres . \\
\hline Federal & 81 & $5,176,710$ \\
Private & 8 & 511,280 \\
State & 7 & 447,370 \\
Indian & $\underline{400}$ & 255,640 \\
Total & 100 & $6,391,000$ \\
\hline
\end{tabular}

ENERGY USE

Arizona Public Service Company provides both electric power and natural gas to Yuma County. The primary source of electrical power in the Yuma area is the 2,085-MW Four Corners Generating Station which is interconnected with the 161-KV United States Bureau of Reclamation transmission network at Parker, Arizona. One-third of the 75-MW capacity at the Yucca Plant in Yuma is allocated to the immediate Yuma area. Two 2.5-MW and two 60-MW natural gas turbines are used for peaking. 


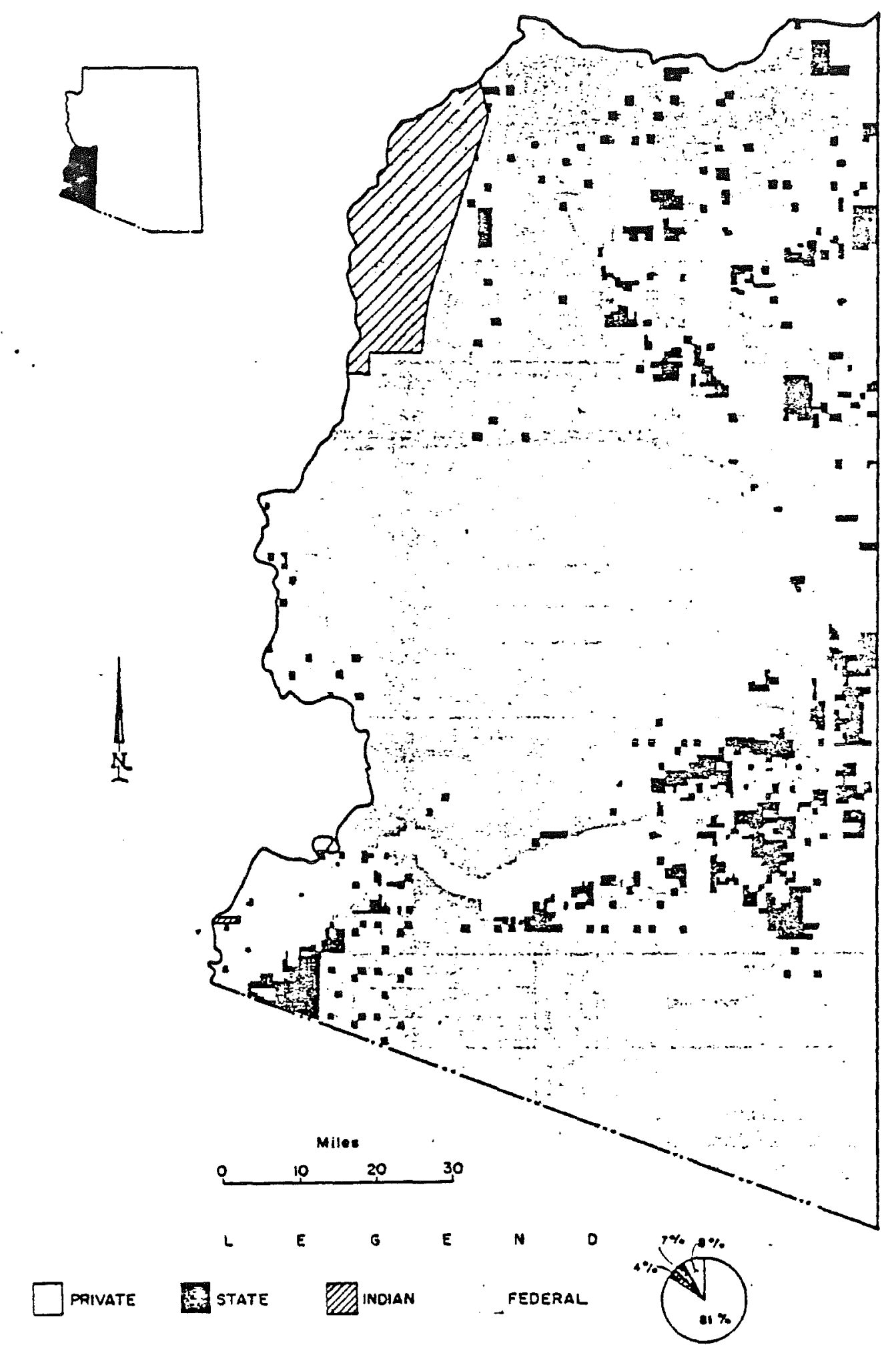

Figure 4: General Land Ownership Map for Yuma County. Source: Arizona Water Comnission (1977) 
WATER

Three alternative futures for water depletion in Yuma County are presented in Figure 5. These alternatives provide a range of possibilities which might emerge depending on factors such as population growth, industrial development and consumer habits and lifestyles.

The rapid population growth projected for Yuma County will result in increased water depletion. However, water depletion associated with the projected population increase is relatively insignificant when compared to anticipated agricultural depletions. The data in Figure 5 show that urban use represents about two percent of total depletions under all three alternatives while agriculture accounts for approximately 95 percent.

Currently, only 900 acre-feet of water per year is consumed for steam electric power generation. Arizona Public Service is planning construction of another electric power generating facility near Bouse, Arizona. As a result, depletions for cooling steam electric power plants are projected to Increase in Yuma County after 1990.

Dependable supplies along the Colorado River are projected to equal depletions. Although users along the river will have a dependable supply, other areas will experience groundwater overdraft. Thus, small deficiencies are projected under Alternatives I, II and III for Yuma County. 


\section{PROJECTED ALTERNATIVE WATER DEPLETIONS \\ AND DEPENDABLE SUPPLY}

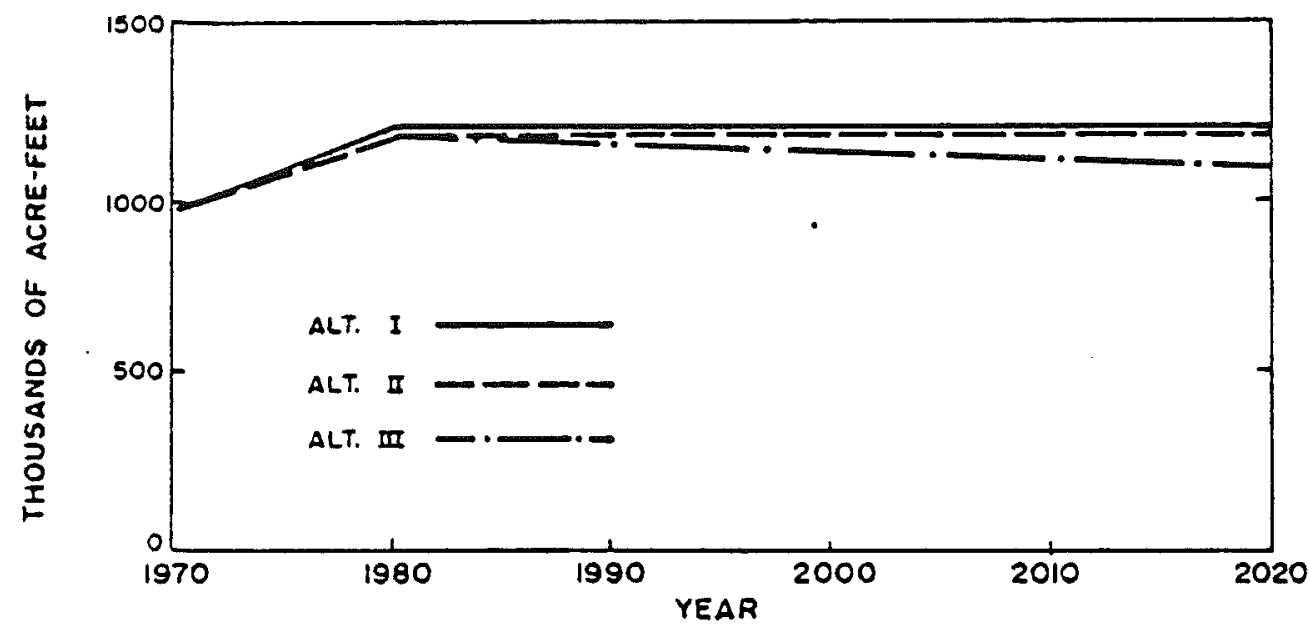

ALTERNATIVE FUTURES SUMMARY

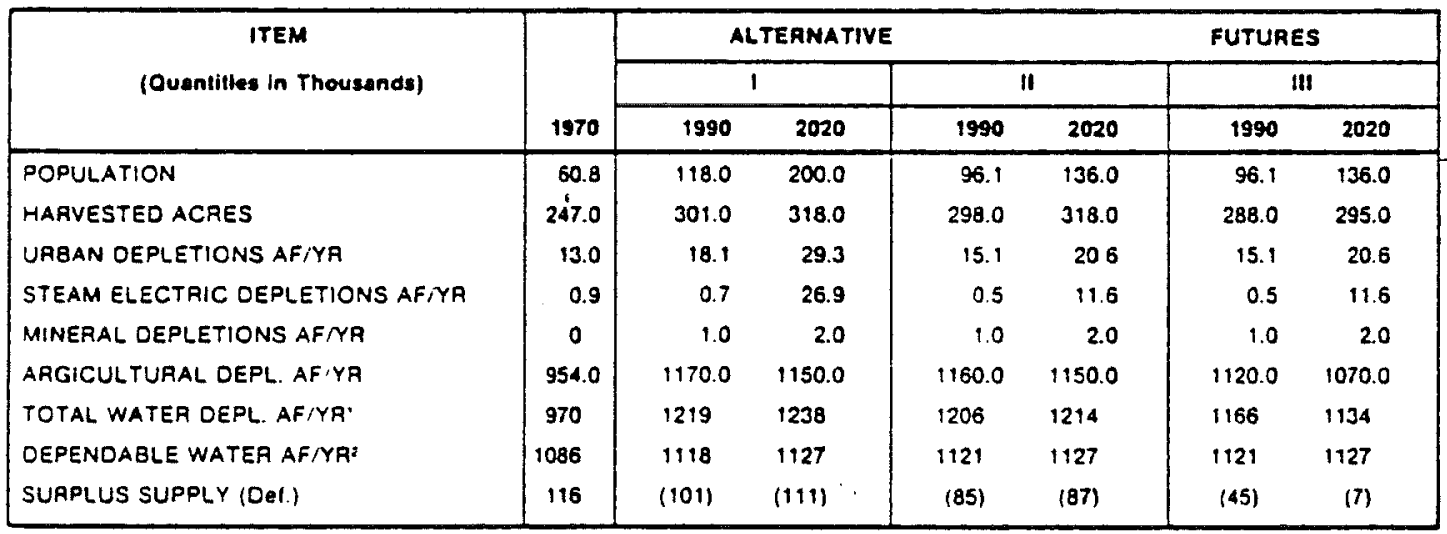

Incluces 2000 acre-leet cepleted tor hisn ind widite purposes in 1970 and 29400 xcre-leet in 1990 and 2920

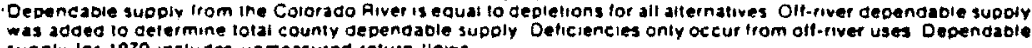
sudoly lor 1970 incluces unmeasured ieturn lows

Figure 5: Projected Alternatives for Water Use in Yuma County. Source: Arizona Water Commission (1977) 
MATCEING GEOTHERMAL RESOURCES TO POTENTIAL USERS

Some prospects for geothermal applications in Yuma County are indicated. Table 4 presents an estimate of industrial process heat requirements on an annual basis for the ready-mix concrete industry. Based on the assumed reservoir temperature of $70^{\circ} \mathrm{C}\left(158^{\circ} \mathrm{F}\right)$ this industry is considered a potential user of geothermal energy. It should be noted that industrial process heat requirements do not include energy consumed for space cooling or heating.

TABLE 4: ESTIMATED PROCESS HEAT ENERGY REQUIREMENTS

Assumed Reservoir Temperature: $70^{\circ} \mathrm{C}$

SIC Code $\quad \frac{\text { Industry Description }}{\text { Ready-Mix Concrete }} \quad \begin{aligned} & \begin{array}{l}\text { Process Heat } \\ \text { Temperature }\end{array} \\ & 6273-5^{\circ} \mathrm{C}\end{aligned}$

Other industries in Yuma which may be able to use geothermal energy for their space heating and/or process heat needs include Blue Bell, Incorporated, The Gowan Company, Southwestern Ice and Coca-Cola Bottling Co. and Sun Printing Company.

Work performed in conjunction with the New Mexico Energy Institute (NMEI) modeled geothermal energy on line as a function of time over the next forty years. For modeling purposes, it was assumed that geothermal energy comes on line when it becomes the lowest cost energy source. Figure 6 presents energy on line assuming a city-owned utility developed the resource; Figure 7 presents energy on line assuming private development of the potential resource. The differences result from differing costs of capital. 


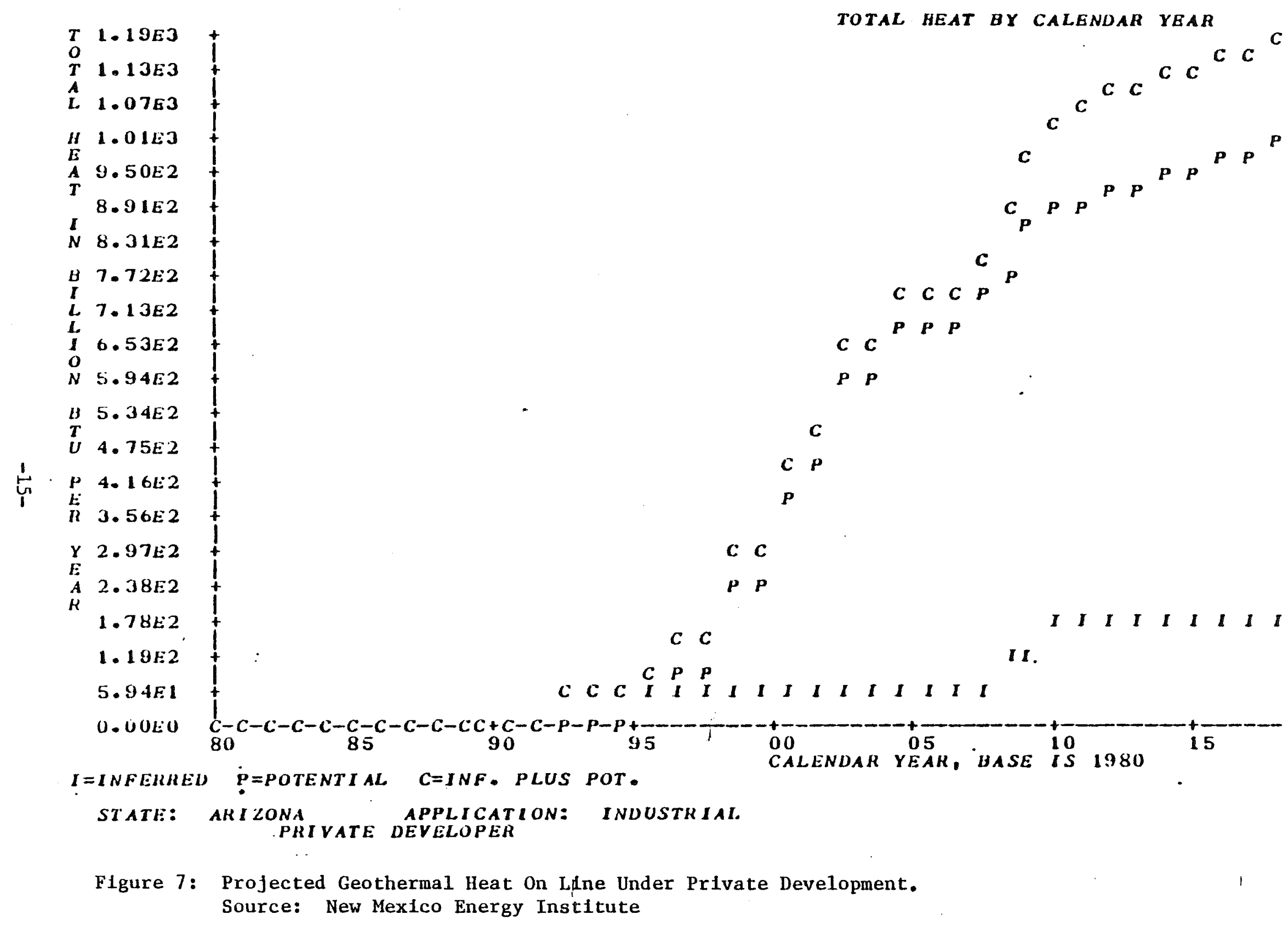


Results from Figures 6 and 7 can be summarized as follows. Under private development, geothermal energy would come on line by 1993 and would grow steadily until 2020. Under city utility development, geothermal energy would be cost competitive by 1989. Thus, city utility development results in faster development of the resource. Table 5 reports energy on line in terms of barrels of oil replaced by geothermal energy annually. It is apparent that in the process heat market, geothermal

TABLE 5: BARRELS OF OIL REPLACED BY GEOTHERMAL ENERGY PER YEAR Process Heat Market

\begin{tabular}{|c|c|c|c|c|}
\hline & 1985 & 1990 & 2000 & 2020 \\
\hline Private Developers & 0 & 0 & 53,393 & 212,500 \\
\hline City Utility & 0 & 9196 & 132,142 & 226,785 \\
\hline
\end{tabular}

energy could replace a significant number of barrels of oil by the . .......

year 2020 .

The NMEI model for predicting geothermal energy on line is discussed more fully in Appendix A.

Modeling comparable to the above work was also performed for the residential and commercial sectors. However, the scope of work was confined to space heating energy requirements. The use of space heating in Yuma County is limited to a $f e w$ winter months and would not justify the establishment of district heating systems. Thus, results from the residential and commercial sectors have been omitted.

Agribusiness and agricultural industries in Yuma County were also identified. Most agricultural processing is concentrated in citrus crops 
and in raising livestock. Future expansion of agricultural processing in Yuma County would have significant benefits for local residents and farmers. Geothermal energy might stimulate a local industry by providing a low-cost energy source suitable for agricultural and livestock processing and irrigation. 
Appendix A

The New Mexico Energy Institute at New Mexico State University has developed a computer simulation model, BTHERM, to assess the economic feasibility of residential and comercial district space heating, hot water heating and industrial process heating using low temperature geothermal energy. Another model, CASH, was developed to depict the growth of geothermal energy on line over the next 40 years as a function of price of competing energy sources. A major assumption of these models is that geothermal energy must be price-competitive with the lowest-cost conventional energy source in order to assure market capture.

Development of a geothermal resource is characterized by large capital outlays, but a long-term geothermal investment has the potential to provide relatively inexpensive energy at a stable price. Unlike natural gas and electricity, however, geothermal energy is an unknown energy involving certain risks such as price and reservoir life and the need for back-up systems. An analysis of the costs and economic competitiveness of geothermal energy must take these uncertainties into account. Thus, costs may be overestimated so that the benefits will not be overstated.

BTHERM models the residential, commercial and industrial sectors of a typical city, each sector having unique energy costs and energy system physical parameters as well as different growth rates. The model possesses the ability to model each sector individually and can analyze the application of geothermal energy to new growth only, to conversion of existing structures or to a combination of both. The model also has the capability to model both private and city-owned utility development of the geothermal resource. 
Output of the model includes the levelized price per million Btu of delivered energy, the discounted present value of investment necessary and the undiscounted values of investments for policy studies. Also, from input of the price and price growth rate of conventional energy, the model determines the discounted or undiscounted values for federal and state taxes, tax credits, royalty rates, property taxes and consumer savings due to conversion from conventional energy to geothermal. Certain limitations of the model have already been suggested. Costs, for example, may be overestimated due to safeguards built into the model to take into account the risks associated with geothermal energy. This overestimation of costs might result in the exclusion of a potential use of geothermal energy. Another limitation is that the price of natural gas is taken as the price of competitive (conventional) energy, but not all users have access to natural gas.

The output of the model is not a substitute for detailed engineering design studies but it is useful for determining order-of-magnitude costs and potential benefits of geothermal energy development. 


\section{BIBLIOGRAPHY}

References used in preparing the Area Development Plans

Arizona Agricultural Statistics 1978, 1979: Phoenix, Arizona, Arizona Crop and Livestock Reporting Service, 68 p.

Arizona Community Profiles, 1981: Phoenix, Arizona, Research Program, Arizona Office of Economic Planning and Development.

Arizona Statistical Review, 1979: Phoenix, Arizona, Valley National Bank of Arizona, 72 p.

Brown, R., 1978, Industrial Process Heat Demand Balance: Golden, Colorado, Solar Energy Research Institute, unpublished draft.

Climatograph of U.S. No. 81 Arizona, 1978: Asheville, North Carolina, National Climate Center.

Dunn, D. and Cox, D.C., 1979, Papers in Community Development No. 2 - SocioEconomic Indicators for Small Towns: Tucson, Arizona, Rural Information Center, $58 \mathrm{p}$.

Energy Analysis of 108 Industrial Processes, 1979: Philadelphia, Pennsylvania, Drexel University.

Energy-Saving Techniques for the Food Industry, 1977, M.E. Casper, editor: Park Ridge, New Jersey, Noyes Data Corporation, 657 p.

Frank, H.J., 1977, Arizona Energy Inventory: 1977: University of Arizona, Tucson, $100 \mathrm{p}$.

Gerber, L.A., Worden, M.A., and Dunn, D., 1980, Papers in Community Development No. 5 - Safford, Arizona: A Trade Area Analysis: Tucson, Arizona, Rural Information Center, $76 \mathrm{p}$.

Gibson, L.J., Worden, M.A., and Solot, M.S., 1979, Papers in Community Development No. 1 - A Citizen's Handbook for Evaluating Community Impacts: Tucson, Arizona, Rural Information Center, $65 \mathrm{p}$.

Hodgson, M.L., 1978, Arizona Job Scene 1985: A Labor Market Information Publication of the Arizona Department of Economic Security, $133 \mathrm{p}$. 
Industrial Waste Heat Survey, 1978, Rocket Research Company.

Inside Phoenix 1979, 1979: Phoenix, Arizona, Phoenix Newspapers, Inc., 152 p.

Inside Phoenix 1981, 1981: Phoenix, Arizona, Phoenix Newspapers, Inc., 128 p.

1981 Directory of Arizona Manufacturers, 1981: Phoenix, Arizona, Phoenix Metropolitan Chamber of Commerce, 200 p.

Phase II - Arizona State Water Plan: Alternative Future, 1977: Phoenix, Arizona, Arizona Water Commission, 145 p.

Population, Employment and Income Projections for Arizona Counties 1977 2000, July 1978 \& 1979: Artzona Department of Economic Security.

Population Estimates of Arizona as of July 1, 1979: Phoenix, Arizona, Arizona Department of Economic Security Report No. 12, 66 p.

Statistical Report for Financial Analysis 1969 - 1979: Phoenix, Arizona, Arizona Public Service Company, 24 p.

Stone, C., 1980, Preliminary Assessment of the Geothermal Potential at the Papago Farms, Papago Indian Reservation, Arizona: State of Arizona Bureau of Geology and Mineral Technology Open-File Report 80-6, 62 p.

Stone, C., 1981, A Preliminary Assessment of the Geothermal Resource Potential of the Yuma Area, Arizona: State of Arizona Bureau of Geology and Mineral Technology Open-File Report 81-4, $28 \mathrm{p}$.

Survey and Analysis of Solar Energy Process Beat Opportunities in Arizona, 1979: University of Arfzona, Department of Nuclear Energy, Energy Management and Policy Analysis Group, Final Report prepared for Arizona Solar Energy Research Commisston under Office of Economic Planning and Development Contract No. 458-78

Swanberg, C.A., Morgan; P., Stoyer, C.H., and others, 1977, An Appraisal Study of the Geothermal Resources of Arizona and Adjacent Areas in New Mexico and Utah and Their Value for Desalination and other Uses: New Mexico Energy Institute Report No. 6, 76 p. 
Tucson Trends 1980, 1980: Tucson, Arizona, Valley National Bank of Arizona and Tucson Newspapers Inc, $88 \mathrm{p}$.

Witcher, J.C., 1979, Proven, Potential and Inferred Geothermal Resources of Arizona and Their Eeat Contents: State of Arizona Bureau of Geology and Mineral Technology Open-File Report 79 -5, 65 p.

Witcher, J,C., 1981, Geothermal Energy Potential of the Lower San Francisco RIver Region, Arizona: J.S. Geological Survey Open-File Report 81-7, 135 P. 